\title{
Kritik Comic dalam Kompetisi Kritik DPR 2018 sebagai Praktik Demokrasi
}

\author{
Ananda Ashari* \\ Program Studi Ilmu Komunikasi, Universitas Telkom, Bandung, Jawa Barat, \\ Indonesia, Email: anandaashario5@gmail.com
}

Adi Bayu Mahadian

Program Studi Ilmu Komunikasi, Universitas Telkom, Bandung, Jawa Barat, Email: adibayumahadian@telkomuniversity.ac.id

\begin{abstract}
Stand-up comedy can function as a medium of entertainment as well as a media channeling people's aspirations including political criticism as a form of democracy. This research uses Teun A. van Dijk's discourse analysis method which is supported by bisociation theory as one of humor theories, with the aim of the research to find out the theme, discourse, humorous discourse display and the role of stand-up comedy as a form of democracy based on Aji Pratama's stand-up comedy in 2018 DPR critics competition. The results of this study explain that the theme raised in the Aji Pratama material is the bad behavior of the DPR with humorous discourse in the form of humor, which is mostly presented in the form of negotiations and conveyed subtly through elements of van Dijk. The phenomenon is an illustration of the form of democracy in Indonesia which is at the same time a contribution of this research to the study of democracy. This research also contributes to the study of humor theory through the use of bisociation theory to show how even critical discourse can be packaged in the form of humor.
\end{abstract}

Keywords: Stand-up comedy, political criticism, discourse analysis, democracy

\begin{abstract}
Abstrak. Stand-up comedy dapat berfungsi sebagai media hiburan sekaligus media penyalur aspirasi masyarakat termasuk kritik politik sebagai wujud demokrasi. Penelitian ini menggunakan metode analisis wacana Teun A. van Dijk yang didukung oleh teori humor Bisosiasi. Tujuan tujuan penelitian untuk mengetahui tema, wacana, tampilan wacana kritik humor serta peran stand-up comedy sebagai bentuk demokrasi yang berdasar pada stand-up comedy Aji Pratama di kompetisi kritik DPR 2018. Hasil penelitian ini menjelaskan bahwa tema yang diangkat dalam materi Aji Pratama adalah perilaku buruk DPR dengan wacana kritik berbentuk humor yang sebagian besar ditampilkan dalam bentuk bisosiasi dan disampaikan secara halus melalui elemen-elemen van Dijk. Adapun fenomena tersebut menjadi gambaran wujud demokrasi di Indonesia yang sekaligus menjadi kontribusi penelitian ini terhadap studi demokrasi. Penelitian ini memberikan berkontribusi pada kajian teori humor melalui penggunaan teori Bisosiasi guna memperlihatkan bagaimana wacana kritik sekalipun dapat dikemas dalam bentuk humor.
\end{abstract}

Kata Kunci: Stand-up comedy, kritik politik, analisis wacana, demokrasi

*Penulis Korespondensi 


\section{PENDAHULUAN}

Diluar dari kemampuan humor menjadi sarana penghibur, humor juga dapat menjadi sarana atau media untuk menyampaikan kritik. Mahadian (2014) mengemukakan bahwa humor dapat menjadi media untuk menyampaikan pendapat, kritik yang tajam, serta bahasan tabu sekalipun dalam bentuk komunikasi yang halus, disertai dengan tawa dan perasaan senang.

Sebagai salah satu genre komedi atau humor, kemampuan stand-up comedy sebagai media kritik sesuai dengan definisi stand-up comedy itu sendiri. Stand-up comedy merupakan jenis komedi, dimana satu orang melakukan monolog yang membahas mengenai berbagai persoalan, realitas, maupun keresahan masyarakat yang diutarakan berdasarkan pengamatan atau pengalaman pribadinya, dan kemudian dikemas dalam bentuk jenaka (Pragiwaksono, 2012).

Pada stand-up comedy, dikenal istilah bit atau perpaduan antara set up dan punch line, yang disatukan menjadi satuan materi. Set up merupakan kalimat yang mengawali joke, dapat berupa premis dan biasanya tidak lucu. Sedangkan punch line, kalimat setelah set up dan merupakan bagian yang lucu atau mengejutkan (Pragiwaksono, 2012).

Hal yang membedakan stand-up comedy dengan bentuk kritik lainnya adalah kritik pada stand-up comedy dikemas dalam bentuk jenaka sehingga lebih santai dan mudah diterima oleh siapapun pendengarnya. Sebagaimana yang dikemukakan oleh Pragiwaksono (2012) "Stand-up comedy dikenal sebagai komedi yang membawa kebenaran akan sering kali membawa kebenaran yang pahit, tapi dibawakan dengan jenaka.”
Walaupun persoalan dikemas dalam bentuk jenaka, humor termasuk stand-up comedy di dalamnya dianggap dapat membuka persoalan-persoalan serius. Leeson (2014) mengemukakan bahwa komedi mampu mengungkapkan kebenaran serta membahas keganjilan, mengkritisi norma-norma budaya yang terdapat pada suatu masyarakat, bahkan mengacaukan persepsi penonton mengenai suatu hal. Selain itu, stand-up comedy mampu membangkitkan isu - isu mengenai penindasan yang diabaikan, dan membentuk narasi baru untuk dibahas kembali (Krefting dalam Chattoo, 2018).

Beberapa comic baik dalam maupun luar negeri telah melakukan stand-up comedy yang mengandung kritik. Salah satunya adalah comic perempuan berdarah Afrika-Amerika, Jackie Mabley yang dengan ciri khas kulit hitamnya, membawakan stand-up comedy dengan memberikan gambaran dan arahan sejak tahun 1920 hingga 1970-an mengenai pengalaman hidup orang Afrika-Amerika yang mengalami perlakuan rasis (Leeson, 2014).

Adanya kebebasan menyampaikan kritik tentunya didukung oleh kualitas domokrasi di suatu negara. Di Indonesia, Dewan Perwakilan Rakyat (DPR) merupakan lembaga pemerintahan yang menjadi pusat demokrasi. Dimana DPR memiliki tugas dan wewenang untuk "menyerap, menghimpun, menampung dan menindaklanjuti aspirasi rakyat (DPR Indonesia, n.d.). Namun dalam kenyataan yang terjadi, banyak pemeberitaan perihal penyelewengan terhadap tugas dan wewenang DPR itu sendiri, sehingga menimbulkan kritik dari masyarakat.

Salah satu fenomena kritik DPR terjadi saat Ketua DPR Republik Indonesia, Bambang Soesatyo membuka kesempatan bagi masyarakat untuk 
memberikan kiritik kepada DPR melalui kompetisi stand-up comedy dengan tema "Kritik DPR". Kompetisi tersebut dilakukan secara langsung di hadapan DPR pada bulan Agustus 2018, dalam rangka memperingati Hari Ulang Tahun (HUT) Republik Indonesia ke-73.

Kompetisi kritik melalui stand-up comedy tersebut menjadi suatu hal yang tidak lazim karena DPR membuka kesempatan untuk dikritik secara langsung, di hadapan mereka sendiri. Selain itu, bentuk kritik yang disampaikan bernuansa humor sehingga berbeda dengan bentuk kritik lainnya yang dibawakan dengan serius. Lomba ini dilaksanakan guna membuktikan bahwa DPR RI terbuka untuk menerima kritik mengenai kinerja DPR RI (Wulandari, 2018)

Hal yang menjadi viral adalah penampilan juara pertama stand-up comedy, yakni Aji Pratama yang menampilkan pembawaan 'nakal' remaja. Aji memberikan kritik berupa sindiran perilaku buruk DPR yang disamakan dengan kenakalan siswa pada umumnya. Kritik di antara dalam bentuk tidur di kelas, bolos, dan korupsi uang Sumbangan Pembinaan Pendidikan (SPP) yang kemudian disindirkan ke perilaku DPR seperti tertidur saat rapat, tidak menghadiri rapat, korupsi uang negara, disertakan dengan kritik lainnya.

Adanya pesan yang dimuat dalam stand-up comedy Aji Pratama merujuk pada kritik politik dengan nuansa humor. Dalam hal ini, stand-up comedy bertujuan sebagai penghibur mampu membawakan kritik yang serius dengan humor sehingga menjadi hal yang mudah diterima dan justru ditertawakan. Kemampuan humor sebagai media kritik politik menjadikan humor sebagai media demokrasi.
Di Afrika Selatan, komedi termasuk stand-up comedy merupakan bentuk demonstrasi mengenai kemarahan atau protes politik yang berada di bawah tekanan ketat Apartheid serta mengenai kemungkinan kebebasan yang dijanjikan oleh demokrasi. Komedi dapat mengarahkan terhadap apa, dimana, dan siapa yang terabaikan atau menjadi minoritas dalam kehidupan (konteks pembahasan problematika politik di Afrika Selatan). Komedi juga memiliki kelebihan dalam pengungkapan realitas karena komedi lebih terbuka dan jujur atas apa yang dibahasnya (Seirlis, 2011).

Menurut Schmidt (1990) humor politik menjadi indikator keterpaduan masyarakat dan hubungannya dengan negara, membantu menjelaskan pandangan orang-orang terhadap peristiwa politik yang terjadi pada masa sekarang dan masa lampau serta terkait prestasi negara dan politisi, menyediakan cara untuk melihat sejarah, terutama dari perspektif masyarakat. Berdasarkan pemahaman tersebut, dapat difahami bagaimana peran humor dalam menghubungkan masyarakat dengan dunia politik. Sebagaimana stand-up comedy dijadikan media untuk menyuarakan pendapat masyarakat, stand-up comedy memiliki kemampuan untuk menjadi sarana demokrasi.

Humor politik dapat menjadi media demokrasi atas kemampuannya menggiring opini publik terhadap kaum penguasa. Mahadian (2014) mengemukakan bahwa "humor politik dapat menjadi sarana unjuk rasa dan pendapat." Dengan kemampuan opini rakyat terhadap berbagai persoalan, humor politik dapat menjadi salah satu tolak ukur derajat demokrasi suatu negara. Semakin berkembang humor politik pada suatu negara dalam konteks kebebasan, maka semakin tinggi pula derajat demokrasi negara tersebut (Mahadian, 2014). 
Beberapa penelitian telah mengkaji humor, termasuk stand-up comedy yang menjadi media untuk menyampaikan kritik, (Risden, 1990; Wijayanti, Suharto, \& Soleh, 2018; Alam, 2016; Anjari, 2015; Burhanuddin, 2017). Penelitian lain telah mengkaji keterkaitan antara humor atau komedi dengan demokrasi, (Seirlis, 2011; Schmidt, 1990; Mahadian, 2014).

Penelitian - penelitian yang telah dilakukan memiliki fokus penelitian masing - masing dengan membahas persoalan tertentu. Sebagian besar, membahas kritik sosial yang terkandung dalam stand-up comedy. Selain itu, penelitian mengenai keterkaitan humor dan demokrasi di Indonesia menggambarkan bagaimana kemampuan humor untuk opini publik kepada kaum elite atau pemerintahan.

Hal yang membedakan penelitian ini dengan penelitian sebelumnya adalah fokus penelitian yang membahas mengenai makna kritik politik pada stand-up comedy Aji Pratama, yang dilaksanakan oleh DPR dan ditujukan secara langsung untuk DPR itu sendiri, dan sekaligus membahas bagaimana wujud demokrasi pada fenomena kompetisi kritik DPR 2018 di Senayan. Selain itu, penelitian ini menggunakan teori humor bisosiasi untuk mendukung metode analisis wacana Van Dijk. Ini belum banyak dilakukan di Indonesia.

Penelitian ini bertujuan untuk menjelaskan makna kritik stand-up comedy Aji Pratama yang merujuk pada tema yang diangkat, wacana-wacana yang dilontarkan dan cara penyampaianya, tampilan wacana kritik dalam bentuk humor, serta menggambarkan bagaimana kondisi demokrasi Indonesia dengan kaitannya pada humor. Selain itu, penelitian ini berfungsi menggambarkan peran humor seperti stand-up comedy sebagai media kritik dan sebagai salah satu wujud demokrasi di Indonesia.

\section{METODE}

Penelitian dilakukan pada materi yang terdapat pada naskah stand-up comedy Aji Pratama. Naskah tersebut didapatkan melalui dokumentasi video pada channel youtube Gunung Haji yang menampilkan video stand-up comedy Aji Pratama pada kompetisi kritik DPR 2018 di Gedung DPR RI, Senayan.

Metode penelitian yang digunakan adalah metode analisis wacana van Dijk yang didukung oleh teori Bisosiasi. Hal tersebut dilakukan guna memberikan dukungan dan gambaran bagaimana keterkaitan antara wacana dan humor, sebagaimana belum ada metode khusus yang dipakai oleh para ilmuan dalam menganalisis wacana-wacana humor.

Teori analisis wacana van Dijk mengandung beberapa elemen sebagai berikut (Sobur, 2009) sebagai berikut.

1. Tematik

Tematik merupakan elemen yang digunakan untuk mengatahui apa yang dikatakan atau yang disebut dengan tema atau topik.

2. Skematik

Skematik merupakan elemen yang menunjukkan bentuk umum, rangkaian, atau alur dari suatu teks.

3. Semantik

Semantik dalam konteks analisis van Dijk merujuk kepada makna lokal atau makna yang timbul akibat adanya hubungan antarkalimat atau antarproposisi. Terdapat beberapa sub elemen dalam semantik, yakni latar, detail, ilustrasi, maksud, pengandaian, dan penalaran. 
4. Sintaksis

Sintaksis merupakan elemen yang menunjukkan cara pengorganisasian atau penempatan kalimat. Sintaksis memiliki beberapa sub elemen seperti koherensi, nominalisasi, bentuk kalimat, proposisi, dan kata ganti.

5. Stilistik

Stilistik merupakan elemen yang mengarahkan pada gaya bahasa atau pemilihan kata yang digunakan oleh komunikator dalam menyampaikan pesannya.

6. Retoris

Retoris merupakan elemen yang berkaitan dengan cara atau gaya penekanan pesan dilakukan. Retoris pula memiliki fungsi dalam melakukan persuasi. Retoris memiliki beberapa sub elemen seperti repetisi, aliterasi, ironi, metonomi, interaksi, eskpresi, metafora, dan visual image.
Adapun teori bisosiasi dapat digambarkan sebagai penyatuan dua konteks asosiasi (situasi atau ide) yang konsisten namun biasanya memiliki logika atau perilaku berbeda sehingga menyebabkan 'explosion' (ledakan). Ledakan dalam bisosiasi dapat diartikan sebagai hal yang tak biasa atau hal yang tak terduga sehingga menimbulkan humor (Koestler, 1989).

Teori ini digunakan untuk melihat bagaimana bentuk atau struktur teks stand-up comedy, yang menggabungkan dua bahasan berbeda (set up dan punch line), dan kemudian jika disatukan akan menjadi makna baru, yakni humor yang menghibur. Bisosiasi merupakan nama yang diciptakan oleh Koestler sebagai karakter penyatuan antara dua situasi atau ide tersebut (L). Selain itu, situasi atau ide tersebut diistilahkan sebagai "matriks pemikiran" yang dalam teori bisosiasi dijelaskan sebagai M1 (sebagai matriks atau situasi pertama) dan M2 (sebagai matriks atau situasi kedua) (Pearce, 2001)

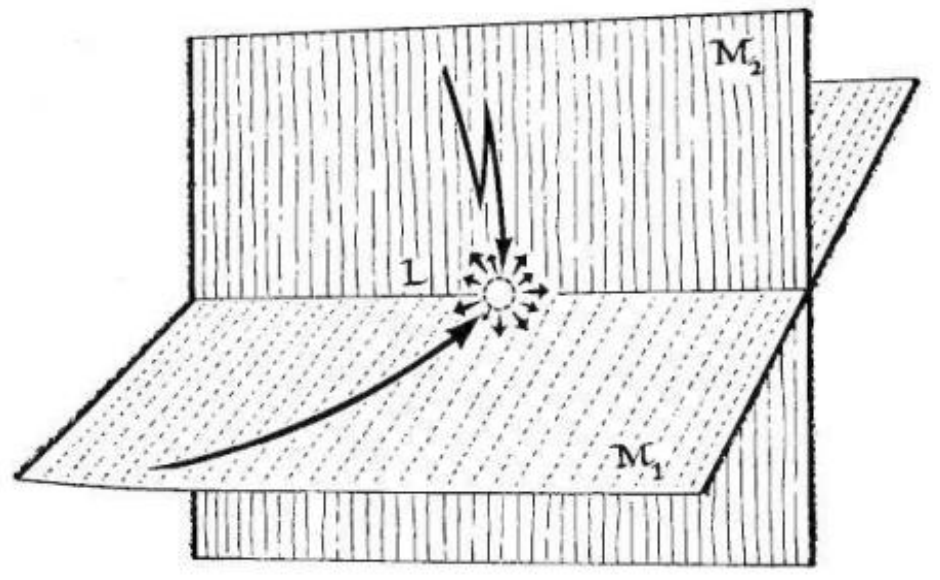

Gambar 1. Penyatuan Dua Matriks Pemikiran dalam Teori Bisosiasi. (Sumber: Pearce, 2001)

Teori bisosiasi membantu elemen sintaksis wacana van Dijk khususnya sub elemen koherensi untuk menggambarkan bentuk atau struktur wacana stand-up comedy Aji Pratama yang mengandung unsur humor. Koherensi sendiri merupakan hubungan antar kalimat atau proposisi yang dihubungkan melalui kata hubung (Sobur, 2009) sehingga memiliki kaitan dengan bisosiasi. 
Terkait wacana dalam materi pada stand-up comedy, Bit merupakan satuan materi dari set up dan punch line. Set up ditempatkan sebagai M1 (situasi pertama) dan punch line ditempatkan sebagai M2 (situasi kedua) pada bisosiasi. Oleh karena itu, wacana-wacana dalam materi stand-up comedy Aji Pratama dapat dianalisis melalui analisis wacana van Dijk yang didukung oleh teori Bisosiasi. Berikut gambaran metode analisis yang digunakan.

Tabel 1. Kerangka Analisis

\begin{tabular}{|c|c|c|}
\hline Struktur Wacana & Hal yang Diamati & Elemen \\
\hline Struktur Makro & TEMATIK (Apa yang dikatakan?) & Topik \\
\hline Superstruktur & $\begin{array}{c}\text { SKEMATIK (Bagaimana pendapat } \\
\text { disusun dan dirangakai?) }\end{array}$ & Skema \\
\hline Struktur Mikro & $\begin{array}{l}\text { SEMANTIK (Makna yang ingin } \\
\text { ditekankan dalam teks berita?) }\end{array}$ & Latar, detail, maksud, penanggapan, nominalisasi \\
\hline Struktur Mikro & $\begin{array}{c}\text { SINTAKSIS (Bagaimana pendapat } \\
\text { disampaikan?) }\end{array}$ & $\begin{array}{l}\text { Bantuk kalimat, koherensi, } \\
\text { kata ganti }\end{array}$ \\
\hline Struktur Mikro & $\begin{array}{c}\text { STILISTIK (Pilihan kata apa yang } \\
\text { dipakai? }\end{array}$ & Leksikon \\
\hline Struktur Mikro & $\begin{array}{l}\text { RETORIS (Bagaimana dan dengan } \\
\text { cara apa penekanan dilakukan?) }\end{array}$ & Grafis, metafora, ekspresi \\
\hline
\end{tabular}

Referensi Tabel: Eelemen Wacana Teun. A van Dijk (Sobur, 2009: 74) yang didukung oleh teori Bisosiasi.

\section{HASIL DAN PEMBAHASAN}

Berdasarkan analisis yang telah dilakukan, maka didapatkan hasil yang menjawab tujuan penelitian sebagai berikut.

\section{Tema dalam Materi Stand-Up Comedy Aji Pratama.}

Pada materi stand-up comedy Aji Pratama saat kompetisi kritik DPR, terdapat empat gagasan pokok atau wacana utama yang disebut pula sebagai sub tema. Sub-sub tema tersebut dijadikan sebagai patokan untuk menyampaikan wacana-wacana berbentuk kritik lainnya. Wacana-wacana pokok tersebut adalah korupsi, tidur saat rapat, tidak menghadiri rapat, dan melakukan kasus suap. Oleh karena itu, dapat disimpulkan bahwa tema utama dalam materi tersebut adalah perilaku buruk DPR.

\section{Wacana-Wacana dalam Materi Stand-Up Comedy Aji Pratama}

Wacana-wacana yang terdapat dalam materi stand-up comedy Aji Pratama dijelaskan secara deduktif, yakni dengan menyebutkan beberapa wacana pokok terlebih dahulu, kemudian membahas setiap wacana pokok tersebut secara lebih luas melalui wacana - wacana kritik lainnya. 
a. Tindakan Korupsi yang Dilakukan oleh DPR

Permasalahan korupsi disebutkan secara jelas sebagai wacana utama di awal pembahasan, yakni dengan menyebutkan bahwa terdapat oknum DPR yang melakukan korupsi. Kemudian dilanjutkan dengan wacana-wacana kritik lainnya seperti jumlah korupsi DPR yang mencapai milyaran, hukuman penjara yang tidak menjerakan, serta singgungan terha-dap fasilitas kendaraan dinas yang dimiliki oleh DPR. Wacana kritik pendukung tersebut memperlihatkan peran elemen detail wacana van Dijk dalam melengkapi wacana utama.

Wacana-wacana tersebut cenderung disampaikan melalui perban-dingan atau persamaan perilaku buruk antara DPR dengan anak STM. Selain itu disampaikan secara halus melalui elemen leksikal dan metafora yang berperan menimbulkan humor, daya tarik, dan mewakili makna sesung-guhnya di balik wacana-wacana tersebut. Beberapa contoh wacana yang disampaikan secara halus, misalnya, "DPR kalo ketahuan korupsi dipenjara, enak".

Wacana dipenjara, enak, sebenarnya memiliki makna bahwa hukuman penjara yang diterima DPR dianggap belum menjerakan. Hal tersebut dilihat dari beberapa pemberitaan kasus korupsi yang dilakukan oleh anggota DPR bahkan mantan ketua DPR RI sendiri, yakni Setya Novanto, serta pemberitaan terkait sel para koruptor yang terbilang nyaman bahkan mewah, seperti pada pemberitaan dengan judul Pura-Pura Penjara pada acara Mata Najwa yang dapat disaksikan di channel youtube Najwa Shihab. Terdapat pula pemberitaan mengenai Ombudsman RI yang telah membenarkan sel mewah Setya Novanto berukuran dua kali lipat dari ukuran sel biasanya (Maulana, 2018). Wacana tersebut didukung dengan wacana:

"ini kalo Aku jadi Presiden, terus ada DPR yang ketahuan korupsi, hukumannya sama, digesperin, digesperin seluruh rakyat Indonesia!"

Wacana digesperin, digesperin seluruh rakyat Indonesia! Menggambarkan harapan masyarakat Indonesia agar terdapat hukum yang lebih tegas terhadap para koruptor. Penggunaan kata digesperin serta kata ganti aku yang merujuk pada komika/anak STM menunjukkan interaksi dan suasana yang santai, sekaligus menguatkan identittas komika sebagai anak STM.

\section{b. Perilaku Buruk DPR yang Tidur saat Rapat}

Pembahasan terkait DPR yang suka tidur saat rapat disebutkan secara gamblang di awal pembahasan, kemudian disamakan dengan kelakuan anak STM yang juga suka tidur di kelas. Pembahasan ini didukung dengan wacana kritik lainnya seperti sindiran terhadap realisasi janjijanji DPR, pertanyaan terkait alasan DPR tidur saat rapat, serta contoh pengandaian alasan DPR tidur saat rapat yang dikaitkan dengan kasus tabrak tiang listrik Setya Novanto. Wacana-wacana kritik pendukung tersebut dilihat sebagai detail dalam elemen wacana van Dijk yang berperan sebagai pelengkap kritik serta menguatkan kritik yang disampaikan.

Kritik disampaikan melalui analogi yang mengaitkan antara perilaku DPR dengan anak STM, serta dengan cara halus melalui penggunaan metafora, ironi, dan leksikal yang memperluas makna yang ingin disampaikan. Elemen-elemen tersebut juga mendukung terciptanya suasana lucu yang kemudian menjadi daya 
tarik bagi penyampaian kritik. Beberapa wacana kritik halus yang disampaikan adalah sebagai berikut.

"Yah Aku penasaran aja gitu apakah rasa iler DPR semanis janji-janjinya Bang tau ga Bang rasa iler DPR Bang? Jilat Bang biar tau Bang.”

Wacana tersebut merujuk pada janji-janji DPR yang bertolak belakang dengan realisasinya, ditandai dengan adanya kata semanis. Dimana kata manis di sini tidak berarti manis secara harfiah seperti yang diartikan oleh KBBI (2020) yaitu manis seperti gula, namun bermakna pembuktian janji-janji DPR.

Selain itu, disinggung pula metafora terkait jilat yang tidak bermakna jilat secara harfiah dalam KBBI (2020) yang berarti mengeluarkan lidah untuk merasakan sesuatu, namun merujuk pada kinerja DPR yang harus lebih diperiksa kebenaran dan pembuktiannya.

Terdapat pula kata ganti Bang untuk menyapa salah satu penonton yang menggambarkan wacana yang akrab dan tidak kaku, serta memperlihatkan keterbukaan posisi antara Aji Pratama dengan khalayak.

\section{c. DPR yang Tidak Menghadiri Rapat}

Pembahasan anggota DPR yang tidak menghadiri rapat diawali dengan wacana anak STM yang menonton sidang paripurna diikuti dengan wacana kritik secara halus dalam kalimat, "Ya di situ Aku liat banyak bangku yang kosong.”

Kritik tersebut merujuk pada anggota DPR yang tidak menghadiri sidang paripurna, disamakan dengan banyaknya siswa STM yang bolos sekolah. Wacanawacana lain yang dibahas adalah pertanyaan alasan DPR tidak menghadiri rapat disertakan wacana berikut.
"Yah soalnya kalo kami ini anak STM yak, bolos tuh ga mungkin sendirian, minimal berdua lah, dan pasti ada satu yang ngajakin.”

Wacana di atas didukung oleh ilustrasi perumpamaan terkait alasan dan cara bolos DPR yang disamakan dengan anak STM melalui penggunaan nama Fahri Hamzah dan Fadli Zon sebagai pemeran, dengan maksud menyinggung DPR itu sendiri. Wacana-wacana tersebut menggunakan elemen ironi, metafora, leksikal, dan kata ganti yang membuat wacana lebih variatif serta menimbulkan makna yang lebih dalam. Selain itu, ilustrasi bolos yang menggunakan nama Fahri Hamzah dan Fadli Zon sebagai pemeran, berfungsi untuk menguatkan wacana kritik sehingga menimbulkan pemahaman yang lebih baik. Penggunaan kata-kata ganti dalam ilustrasi bolos seperti Zon yang mengarah pada Fadli Zon juga menambahkan suasana humor. Oleh karena itu, terlihat kesesuaian antara elemen van Dijk dan hasil penelitian.

\section{d. DPR Melakukan Kasus Suap}

Pembahasan terkait DPR yang melakukan suap disebutkan secara jelas di awal pembahasan, disertai dengan penjelasan anak STM yang melakukan kasus suap kepada adiknya karena ketahuan merokok. Penjelasan tersebut dilanjutkan dengan wacana kritik yang disampaikan secara tidak langsung, yakni:

"Yah karena Aku DPR banget kan dan Aku cinta orde baru, jadi paginya adek Aku ngadu, malemnya adek Aku ilang."

Wacana tersebut merujuk pada perilaku DPR yang melakukan suap untuk menghindari pelaporan terkait kesalahan yang dilakukan. Adanya kata banget yang dalam KBBI (2020) berarti sangat, dapat dimaknai sebagai hal yang telah melekat 
pada diri DPR dalam konteks penyelewengan kekuasaan.

Wacana ini juga menggambarkan pandangan masyarakat Indonesia terkait pemerintahan orde baru. Masa pemerintahan orde baru dapat dilihat sebagai masa pemerintahan yang otoriter, anti kritik, serta membahayakan pihak yang mengkritik pemerintah dan ingin menegakkan kebenaran (Raditya, 2018).

Pembahasan kasus suap juga disampaikan melalui ilustrasi persamaan dan perbandingan tindakan suap yang dilakukan oleh DPR dan anak STM. Pembahasan tersebut juga menggunakan elemen metafora dan leksikal yang memperdalam dan memperluas makna atau kritik yang disampaikan serta menambah nuansa humor. Hal tersebut menggambarkan peran elemen-elemen van Dijk dalam penggambaran makna wacana stand-up comedy Aji Pratama.

\section{Wacana Kritik Ditampilkan dalam Bentuk Humor}

Pada materi stand-up comedy Aji Pratama, sebagian besar wacana kritik yang disampaikan mengandung unsur bisosiasi, yakni dengan wacana pengantar di awal pembahasan atau disebut sebagai matriks pemikiran satu (M1), kemudian diikuti dengan wacana lain yang disebut sebagai matriks pemikiran kedua (M2).

M1 dan M2 ini memiliki logika yang berbeda sehingga jika disatukan akan menimbulkan humor. M1 sendiri dalam stand-up comedy ditempatkan sebagai set up, sedangkan M2 ditempatkan sebagai punchline, yang kemudian penyatuan keduanya disebut sebagai bit. Penyatuan kedua wacana tersebut pada akhirnya menghasilkan sebuah makna dan kesan humor.

Selain unsur bisosiasi, wacana wacana kritik berbentuk humor ditandai dengan adanya penyampaian kritik secara halus atau secara tidak langsung melalui elemen-elemen van Dijk seperti kata ganti, leksikal, metafora, dan ironi (sindiran). Berikut contoh wacana kritik pada materi stand-up comedy Aji Pratama yang ditampilkan dalam bentuk humor baik melalui penggunaan unsur bisosiasi maupun elemen-elemen van Dijk (metafora, ironi, leksikal, dan kata ganti):

\section{"Yak Aku baru lulus sekolah, dan di sekolah Aku nih termasuk murid yang nakal. Yah, seperti murid nakal pada umumnya gitu, bolos, tidur di kelas, korupsi duit SPP, dan setelah lulus Aku ikut lomba kritik DPR, disuruh kritik dirinya sendiri. Yak, yak gimana gitu Aku sama DPR tuh sama. Kita nih satu passion Pak, satu lifestyle. Pokoknya kalian tuh panutankulah!"}

Pada wacana di atas, wacana tentang perilaku buruk anak STM merupakan wacana pertama atau disebut sebagai set up. Adapun wacana terkait kritik dirinya sendiri, passion, lifestyle, dan panutankulah merupakan wacana kedua atau disebut dengan punchline. Berdasarkan kedua wacana tersebut, terlihat konsep yang berbeda antara keterangan terkait anak STM dengan DPR. Namun ketika disatukan menghasilkan makna kritik terhadap perilaku buruk DPR.

Pada wacana tersebut, juga
mengandung elemen leksikal yang terkandung dalam metafora seperti passion dan lifestyle serta terkandung pada ironi seperti kritik dirinya sendiri dan panutankulah. Elemen - elemen tersebut mengambarkan bahwa kritik tersebut sebenarnya diarahkan pada konteks buruk kegemaran dan gaya hidup DPR. 
Berdasarkan elemen - elemen yang ada, kritik yang seharusnya disampaikan secara serius, justru dibawakan dengan kalimat yang bercanda, namun tetap mengandung makna kritik yang ingin disampaikan. Adapun pemilihan kata $A k u$ menunjukkan kekuatan identitas dari anak STM sehingga menjadikan wacana lebih jelas dan menarik.

\section{Stand-up comedy Aji Pratama sebagai Bentuk Demokrasi}

Berangkat dari fenomena kompetisi kritik DPR di Senayan pada Agustus 2018, dapat diketahui bahwa yang menjadi sasaran kritik adalah DPR itu sendiri. DPR merupakan lembaga tinggi negara yang memiliki tugas untuk mengayomi rakyat. Pemilihan anggota DPR sendiri merupakan hasil dari pilihan rakyat, dimana rakyat tentu memiliki harapan besar dalam pemenuhan hakhaknya melalui wakil rakyat (DPR) yang mereka pilih.

Walaupun memiliki peran dalam mewakili rakyat dan berkewajiban untuk mengayomi rakyat, sebagai lembaga tinggi DPR merupakan institusi yang memiliki kekuasaan besar di Indonesia. Sehingga, kekuasaan yang dimiliki dapat menawarkan berbagai persoalan yang mengarahkan pada pemenuhan tugas dan wewenang, atau justru sebaliknya.

Tidak dapat dimunafikkan bahwa DPR pun telah menjalankan tanggung jawab dan wewenangnya dalam mengayomi rakyat melalui segala kegiatan atau kebijakan yang telah diterapkan. Namun di sisi lain, seringkali terdapat pemberitaan buruk terkait DPR.

Pemberitaan DPR yang melakukan korupsi merupakan salah satu pemberitaan yang membuktikan adanya penyelewengan tugas dan wewenang DPR itu sendiri, dimana DPR sebagai wakil rakyat justru menggunakan hak rakyat untuk kepentingan pribadi. Pemberitaan besar terkait korupsi DPR justru datang dari Setya Novanto pada bulan April 2018, yang pada masanya menjabat sebagai ketua DPR RI periode 2014-2019. Setya Novanto terbukti melakukan korupsi EKTP dengan penerimaan uang sebesar USD 7, 3 juta dan dijatuhi hukuman penjara selama 15 tahun (Detiknews, 2018).

Kasus lainnya adalah kasus suap yang melibatkan Wakil Ketua Komisi VII DPR dari Partai Golkar Eni Maulani Saragih pada bulan Juli 2018 yang diduga menerima uang sejumlah $\mathrm{Rp} 4,8$ miliar yang didapatkan dari kontrak kerja sama pembangunan PLTU Riau-1 di Riau (BBC, 2018).

Beberapa penyelewengan lain juga terjadi seperti tidur saat rapat paripurna hingga tidak menghadiri rapat. Salah satu pemberitaan kembali menyoroti Setya Novanto selaku ketua DPR RI periode 2014-2019 yang datang terlambat kemudian beberapa kali tertidur saat rapat paripurna yang membahas Perppu No 2 Tahun 2017 tentang Organisasi Kemasyarakatan (Ormas) di Gedung DPR RI, Senayan, pada tanggal 24 Oktober 2017 (Bomantama, 2017).

Pemberitaan lain mengenai absennya anggota DPR sebanyak 175 orang di awal rapat paripurna DPR terkait pemngambilan keputusan Rancangan Undang - Undang Penyelenggaraan Pemilihan Umum (RUU Pemilu) pada tanggal 20 Juli 2017 (Sarwanto, 2017).

Penyelewengan tugas dan
wewenang tersebut r tentunya
menimbulkan kritik dari masyarakat.
Salah satu bentuk kritik disampaikan
melalui stand-up comedy yang dilakukan
oleh para komika.

Penyelewengan tugas dan wewenang tersebut tentunya menimbulkan kritik dari masyarakat. Salah satu bentuk kritik disampaikan oleh para komika. 
Salah satu kritik yang ditujukan kepada DPR disampaikan oleh Aji Pratama pada kompetisi kritik DPR tanggal 28 Agustus 2018 di Gedung Nusantara III DPR RI, Senayan, Jakarta (Herdi, 2018). Kompetisi tersebut diselenggarakan oleh lembaga DPR itu sendiri sebagai peringatan Hari Ulang Tahun (HUT) Republik Indonesia yang ke 73, guna membuktikan bahwa DPR RI terbuka untuk menerima kritik mengenai kinerja DPR RI (Wulandari, 2018). Kesempatan tersebut dimanfaatkan oleh Aji Pratama untuk mengungkapkan kritik yang telah dikemas dalam bentuk jenaka, yakni melalui stand-up comedy, dan disampaikan langsung di hadapan DPR termasuk para petinggi DPR seperti Fadli Zon dan Fahri Hamzah.

Kritik yang disampaikan oleh Aji Pratama mengenai perilaku buruk DPR termasuk kinerja DPR di dalamnya. Beberapa kritik yang disampaikan adalah tindakan korupsi DPR yang mencapai milyaran rupiah, hukuman penjara yang dianggap tidak menjerakan bagi para koruptor, fasilitas kendaraan dinas yang dimiliki oleh DPR, serta kasus suap yang dilakukan oleh DPR. Selain itu, kritik yang disampaikan juga mengarah pada kurangnya sikap partisipatif anggota DPR yang tidur atau tidak hadir saat rapat, seperti saat rapat paripurna. Disampaikan pula sindiran terhadap realisasi janji-janji DPR, serta sindiran terkait masa pemerintahan orde baru, yang diidentikkan sebagai masa pemerintahan yang anti kritik dan memabahayakan bagi pihak yang menegakkan keadilan.

Ketika wacana-wacana kritik tersebut disampaikan secara langsung di hadapan para anggota DPR, hal yang terlihat adalah eskpresi para DPR yang menunjukkan bentuk penerimaan. Hal tersebut terlihat dari bagaimana DPR diam sejenak untuk menyimak wacana-wacana kritik, sesekali memberikan tanggapan yang mendukung lelucon, tertawa bahkan tertawa lepas disertai tepuk tangan.

Fenomena tersebut pada dasarnya menjadi gambaran terkait peran stand-up comedy sebagai media bagi masyarakat dalam mengemukakan kritik atau aspirasi terhadap pihak yang berkuasa atas penyelewengan kekuasaan yang diemban. Dalam konteks penelitian ini, penyelewengan kekuasaan dilakukan oleh wakil rakyat sendiri, yaitu DPR. Hal tersebut menimbulkan protes dari rakyat melalui stand-up comedy yang merupakan salah satu media demokrasi.

Terdapat beberapa kajian yang membahas terkait stand-up comedy yang mengandung makna kritik. Salah satu kajian yang menjadi referensi adalah penelitian "Stand Up Comedy Indonesia Sebagai Media Kritik Sosial (Analisis Wacana Stand Up Comedy Indonesia Season 4 di Kompas TV)" oleh Syamsul Alam.

Pada penelitian ini, terdapat empat pertunjukan stand-up comedy yang mengandung kritik sosial, yakni "Suara Minor dari Timur" oleh Abdur Arsyad, "Menjadi Caleg" oleh Dzawin, "(Pemilu) Service Printer" oleh Dodit, dan "BlackCampaign" oleh David Nurbiyanto (Alam, 2016).

Hasil penelitian yang didapatkan menggambarkan bahwa secara keseluruhan penampilan stand-up comedy mengandung unsur informasi, edukasi, dan hiburan. Tema kritik sosial yang didapatkan mengarah kepada pemerintah yang terbagi dari dua tema besar yakni suara minoritas dan pelaksanaan pemilu. Kemudian, pewacanaan kritik dilakukan tidak hanya dengan penampilan yang berhubungan dengan fisik, tapi juga memperhatikan hal-hal yang ada dalam wacana dan bagaimana wacana tersebut disampaikan (Alam, 2016). 
Berdasarkan hasil penelitian tersebut, dapat difahami bahwa materi stand-up comedy mampu menawarkan informasi, edukasi, yang sekaligus menghadirkan hiburan. Hal tersebut selaras dengan fokus penelitian ini yang mempelari makna kritik dari wacanawacana yang dilontarkan oleh Aji Pratama.

Adapun terkait tema, walaupun penelitian Syamsul Alam mengacu pada kritik sosial, tetapi dari keempat penampilan stand-up comedy yang dikaji semuanya berkaitan dengan pemerintahan. Berdasarkan hal tersebut, dapat difahami bahwa stand-up comedy memiliki kemampuan untuk menggiring kritik, pendapat, dan aspirasi masyarakat kepada kaum penguasa (pemerintah).

Hasil terakhir adalah pewacanaan kritik sosial, yang tidak hanya bergantung pada penampilan fisik namun juga hal-hal yang terdapat dalam wacana tersebut seperti elemen detail, penuturan dan retoris. Hal tersebut selaras dengan hasil penelitian ini terkait wacana - wacana yang disampaikan oleh Aji Pratama serta bagaimana wacana tersebut disampaikan, walaupun dalam penelitian ini tidak membahas hal yang berhubungan dengan penampilan fisik seperti pengaturan suara, mimik wajah, gaya tubuh, dll.

Terkait pewacanaan kritik sosial yang memiliki hubungan dengan wacanawacana kritik dan cara penyampaian kritik politik Aji Pratama, pada penelitian kritik politik stand-up comedy Aji Pratama ini, lebih dijelaskan bagaimana elemenelemen wacana van Dijk berperan dalam mendukung wacana kritik. Dimana elemen metafora dan leksikal yang disebutkan di penelitian Syamsul Alam sebagai unsur hiburan dan edukasi, pada penelitian ini dijelaskan lebih dalam dengan kemampuannya menggiring maksud sebenarnya atau makna sesungguhnya dari wacana-wacana kritik yang disampaikan.
Tidak hanya dengan elemen leksikal dan metafora, namun juga ditambahkan dengan elemen ironi atau sindiran, dan kata ganti. Sehingga, pesan - pesan kritik yang disampaikan dapat lebih difahami maknanya. Selain itu, pewacanaan kritik pada penelitian ini dikaji dengan memperhatikan bagaimana wacana kritik ditampilkan dalam humor. Bagaimana struktur kalimat stand-up comedy yakni set up dan punch line dihubungkan dengan M1 dan M2 teori humor bisosiasi, yang sama - sama merupakan dua konsep berbeda jika disatukan akan menghasilkan humor, serta dijelaskan pula bagaimana wacana humor stand-up comedy didukung oleh elemen-elemen Van Dijk seperti metafora, leksikal, kata ganti, dan ironi.

Tidak hanya mengkaji wacana kritik, penelitian ini pula menggambarkan wujud demokrasi di Indonesia melalui fenomena stand-up comedy Aji Pratama pada kompetisi krtik DPR 2018.

\section{KESIMPULAN}

Berdasarkan hasil analisis dan pembahasan yang telah dipaparkan, maka didapatkan kesimpulan sebagai inti jawaban dari pertanyaan-pertanyaan penelitian bahwa tema yang diangkat dalam materi stand-up comedy Aji Pratama adalah perilaku buruk DPR.

Wacana-wacana kritik yang disampaikan oleh Aji Pratama terdiri dari empat wacana utama yang juga berperan sebagai sub tema, yakni tindakan korupsi, DPR yang tidur saat rapat, DPR tidak menghadiri rapat, dan kasus suap yang dilakukan oleh DPR. Pembahasan empat wacana tersebut disertai dengan wacanawacana kritik lainnya yang memperluas dan menguatkan makna kritik yang disampaikan. Secara umum, wacana disampaikan secara gamblang (terus terang) dan juga secara halus (tersirat) yang penyajiannya mengandung keenam 
struktur wacana van Dijk serta dukungan teori Bisosiasi.

Penyampaian wacana kritik berbentuk humor pada dasarnya menggambarkan wacana kritik yang sebagian besar disampaikan dalam bentuk bisosiasi. Selain dalam bentuk bisosiasi, wacana kritik berbentuk humor disampaikan secara halus (tersirat) melalui penggunaan elemen-elemen van Dijk, khusunya metafora, ironi, leksikal, dan kata ganti.

Fenomena Stand-up comedy Aji Pratama menggambarkan bagaimana masyarakat melalui stand-up comedy menyampaikan kritik terhadap DPR sebagai lembaga wakil rakyat di Indonesia atas penyelewengan kekuasaan yang dimiliki, sebagai wujud demokrasi.

Pada sisi pengembangan ilmu pengetahuan, peneliti menyarankan agar penelitian terkait wacana humor dapat semakin dikembangkan, guna mendukung tersedianya metode yang lebih relevan.
Sebagaimana, metode penelitian analisis wacana van Dijk merupakan metode penelitian untuk teks secara umum, bukan dikhsusukan untuk teks atau wacana humor. Selain itu, peneliti juga menyarankan agar masyarakat semakin kritis terhadap permasalahan pemerintahan yang terjadi sehingga dapat memberi masukan dan kritikan yang lebih bijak melalui cara yang lebih kreatif, seperti stand-up comedy.

Kontribusi terhadap studi tentang demokrasi Indonesia, yaitu dengan memberikan deskripsi terkait salah satu wujud peristiwa demokrasi yakni penyampaian kritik melalui stand-up comedy pada kompetisi kritik DPR 2018. Selain itu, penelitian ini juga berkontribusi dalam kajian terkait teori humor, dimana dalam penelitian ini menggunakan teori humor Bisosiasi yang memperlihatkan bagaimana struktur wacana dalam konteks kritik sekalipun dapat ditampilkan atau dikemas dalam bentuk wacana humor

\section{Daftar Pustaka}

Alam, S. (2016). Stand Up Comedy Indonesia sebagai Media Kritik Sosial (Analisis Wacana Stand Up Comedy Indonesia Season 4 di Kompas TV) (UIN Alauddin Makassar).

https://doi.org/https://doi.org/10. 3929/ethz-b-000238666

Anjari, M. W. (2015). Kandungan Kritik Sosial dalam Stand Up Comedy (Analisis Isi Kualitatif pada "Stand Up ComedyMesakke Bangsaku”, "Stand Up ComedyIndonesia Kompas TV", dan "Stand Up Comedy ShowMetro TV”) (Universitas Muhammadiyah Malang). Retrieved from http://eprints.umm.ac.id/22174/
BBC. (2018). Uang Suap Anggota DPR dari Partai Golkar Eni Saragih untuk "Ongkos Politik"? Retrieved January 11, 2020, from https://www.bbc.com/indonesia/ majalah-44777538

Bomantama, R. (2017). Datang Terlambat, Setya Novanto Tertidur saat Sidang Paripurna DPR Membahas Perppu Ormas. Retrieved January 11, 2020, from Tribunnews.com website: https://www.tribunnews.com/nasi onal/2017/10/24/datangterlambat-setya-novanto-tertidursaat-sidang-paripurna-dprmembahas-perppu-ormas 
Burhanuddin. (2017). Representasi kritik Sosial dalam Tayangan Stand Up Comedy Indonesia (Analisis Semiotika Dekonstruksi). Komodifikasi, $\quad 5, \quad$ 106-121. Retrieved from http://journal.uinalauddin.ac.id/index.php/Komodif ikasi/article/view/5511

Chattoo, C. B. (2018). A funny matter: Toward A Framework for Understanding the Function of Comedy in Social Change. Humor, $o(0)$.

https://doi.org/10.1515/humor2018-0004

Detiknews. (2018). Terbukti Korupsi eKTP, Setya Novanto Divonis 15 Tahun Penjara. Retrieved January 11, 2020, from Detiknews website: https://news.detik.com/berita/d3987879/terbukti-korupsi-e-ktpsetya-novanto-divonis-15-tahunpenjara

DPR Indonesia. (n.d.). Tugas dan Wewenang DPR. Retrieved from Dewan Perwakilan Rakyat Republik Indonesia website: http://dpr.go.id/tentang/tugaswewenang

Herdi, M. (2018). Terang-Terangan Meledek Anggota DPR, Pelajar STM Diberi Hadiah Vespa. Retrieved from Liputan 6 website: https://www.liputan6.com/otomot if/read/3636519/terang-teranganmeledek-anggota-dpr-pelajar-stmdiberi-hadiah-vespa

KBBI. (2020). Kamus Besar Bahasa Indonesia. Retrieved from https://kbbi.kemdikbud.go.id/

Koestler, A. (1989). The Act of Creation. England: Arkana.
Leeson, F. (2014). " The Funniest Woman in the World ": Jackie 'Moms , Mabley and Redefining Political Activism in the Modern Black Freedom Struggle. Wellesley College.

Mahadian, A. B. (2014). Humor Politik sebagai Sarana Demokratisasi Indonesia. Ikatan Sarjana Komunikasi Indonesia. Retrieved from

https://openlibrary.telkomuniversi ty.ac.id/pustaka/files/99920/articl e_f/humor-politik-sebagai-saranademokratisasi-indonesia-masadepan-komunikasi-masa-depanindonesia-demokratisasimasyarakat-plural-konferensinasional-komunikasi-november2014.pdf

Maulana, Y. (2018). Terungkap Sel Mewah Setya Novanto di Lapas Sukamiskin, Ini 7 Perbedaan Sel Asli dan Sel Palsu. Retrieved from Nasional website: https://www.tribunnews.com/nasi onal/2018/o9/16/terungkap-selmewah-setya-novanto-di-lapassukamiskin-ini-7-perbedaan-selasli-dan-sel-palsu

Pearce, M. (2001). Notes on The Act of Creation by Arthur Koestler The Bisociation of Matrices. Science, 15 .

Pragiwaksono, P. (2012). Merdeka dalam Bercanda. Bentang: Yogyakarta.

Raditya, I. N. (2018). Menggugat Soeharto yang Menyalahgunakan Pancasila. Retrieved January 11, 2020, from https://tirto.id/menggugatsoeharto-yang-menyalahgunakanpancasila-cLtN 
Risden, E. L. (1990). The Owl and the Nightingale: Postmodernist Play and Medieval Stand-Up Comedy. Humor, 3(4), 403-413. Retrieved from

https://www.degruyter.com/abstr act/j/humr.1990.3.issue-

4/humr.1990.3.4.403/humr.1990. 3.4.403.xml

Sarwanto, A. (2017). Ada 175 Anggota DPR Absen di Awal Rapat Paripurna RUU Pemilu. Retrieved January 11, 2020, from https://www.cnnindonesia.com/na sional/20170720111814-32229115/ada-175-anggota-dprabsen-di-awal-rapat-paripurnaruu-pemilu

Schmidt, S. (1990). Elitelore in Politics: Humor versus Mexico ' s Presidents. Latin American Lore, 1 , 91-108.

Seirlis, J. K. (2011). Laughing All the Way to Freedom?: Contemporary StandUp Comedy and Democracy in South Africa. Humor, 24(4), 513530.

https://doi.org/10.1515/HUMR.20 11.028
Sobur, A. (2009). Analisis Teks Media. Bandung: PT Remaja Rosdakarya.

Wijayanti, L. M., Suharto, T., \& Soleh, D. R. (2018). Kritik Sosial dan Nilai Moral dalam Stand Up Comedy Indonesia Episode 7 di Televisi Nasional Kompas (Analisis Wacana Tekstual dan Kontekstual). o6(02), 21-33. Retrieved from http://ejournal.unipma.ac.id/index.php/wi dyabastra/article/view/3594

Wulandari, F. (2018). Aji Pratama Membuat Bamsoet dan Para Juri Stand Up Comedy TerpingkalPingkal. Retrieved from Tribunnews.com website: http://www.tribunnews.com/nasio nal/2018/o8/30/aji-pratamamembuat-bamsoet-dan-para-juristand-up-comedy-terpingkalpingkal 
Jurnal komunikasi, Volume 14, Nomor 2, April 2020, Hal 139-154 